\title{
The Nature of the Place
}

A Study of Great Plains Fiction

Diane Dufva Quantic

Drawing upon studies by cultural geographers, historians, and literary critics, Diane Dufva Quantic offers insightful readings of a staggering array of authors, including Willa Cather, Wright Morris, Mari Sandoz, Laura Ingalls Wilder, Frederick Manfred, Wallace Stegner, and Bess Streeter Aldrich. She considers the literature of the Plains and neighboring regions from early representations in such works as James Fenimore Cooper's The Prairie, published in 1827 , through such contemporary authors as Douglas Unger and Ron Hansen. \$25 cloth

\section{Talking Up a Storm}

Voices of the New West

Gregory L. Morris

In interviews with fifteen contemporary writers of the American West, Gregory L. Morris demonstrates what these widely divergent talents have in common: they all redefine what it is to be a western writer.

Morris talks with Ralph Beer, Mary Clearman Blew, Elizabeth Cook-Lynn, James Crumley, Ivan Doig, Gretel Erlich, Richard Ford, Molly Gloss, Ron Hansen, John Keeble, William Kittredge, David Long, Thomas McGuane, Amy Tan, and Douglas Unger.

$\$ 25$ cloth

University of

Nebraska Press

$312 \mathrm{~N} 14$ th

Lincoln NE 68588

800-755-1105

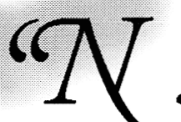




\title{
CASE STUDIES IN CONTEMPORARY CRITICISM
}

\author{
Series Editor: Ross C Murfin, University of Miami
}

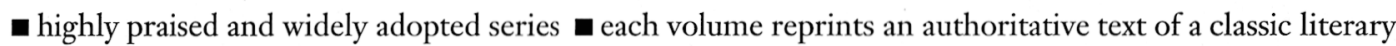
work together with 5 critical essays representing 5 contemporary critical approaches $\mathbf{m}$ each critical essay has been especially written or edited for undergraduates and is preceded by an introduction (with bibliography) to that critical perspective $\mathbf{a}$ the work itself is preceded by an introduction providing important biographical and historical contexts and followed by a survey of critical responses since publication

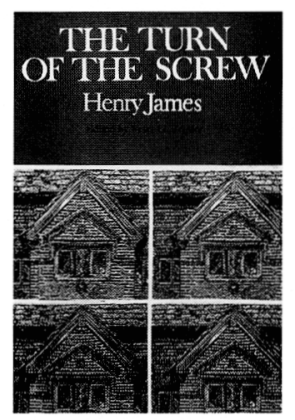

THE TURN OF THE SCREW Henry James

Edited by

Peter G. Beidler, Lebigh University

1995/paper 320 pages $/ \$ 6.50$ net

Reader-Response Criticism:

Wayne C. Booth

Deconstruction: Shoshana Felman

Psychoanalytic Criticism: Stanley Renner

Feminist Criticism: Priscilla L. Walton

Marxist Criticism: Bruce Robbins

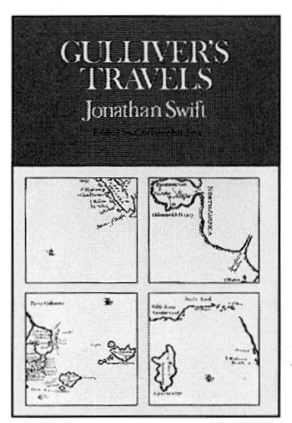

GULLIVER'S
TRAVELS
Jonathan Swift
Edited by
Christopher Fox,
University of
Notre Dame
1995/paper
496 pages/\$7 net

Feminist Criticism: Felicity A. Nussbaum

The New Historicism: Carole Fabricant

Deconstruction: Terry Castle

Reader-Response Criticism:

Michael J. Conlon

Psychoanalytic Criticism: Carol Barash

\section{Coming in the Fall}

\section{GREAT EXPECTATIONS}

\section{Charles Dickens}

Edited by Janice Carlisle, Tulane University

August 1995/paper/624 pages/\$7 net

Psychoanalytic Criticism: Peter Brooks

Deconstruction: Edward W. Said

Feminist Criticism: Hilary Schor

Gender Criticism: William A. Cohen

Cultural Criticism: Jay Clayton

\section{Available in 1996}

\section{JANE EYRE}

\section{Charlotte Brontë}

Edited by Beth Newman, Southern

Methodist University

December 1995/paper/592 pages/\$6.50 net

\section{HEART OF DARKNESS \\ Joseph Conrad}

Second Edition

Edited by Ross C Murfin, University of Miami

December 1995/paper/304 pages/\$6 net

\section{WALDEN}

\section{Henry David Thoreau}

Edited by Michael Meyer, University

$$
\text { of Connecticut }
$$

December 1995/paper/700 pages/\$7 net

\section{Bedford Books of St. Martin's Press For exam copies, call 1-800-446-8923}

